\title{
The Performance Operation of Zeolite as Membrane with using Laundry Waste Water
}

\author{
Alia Damayanti ${ }^{*}$, Tika Kumala Sari ${ }^{1}$, Anshah Silmi Afifah ${ }^{1}$, Sutikno², Lantip Tri Sunarno ${ }^{3}$ and Eddy S Soedjono ${ }^{1}$ \\ ${ }^{1}$ Environmental Engineering Department, Faculty of Civil Engineering and Planning, The Institute of Technology (ITS ), Campus Sukolilo ITS Surabaya, Jl. Arief Rahman \\ Hakim, Surabaya, Indonesia \\ ${ }^{2}$ Statistics, Faculty of Mathematics and Natural Sciences, The Institute of Technology (ITS), Campus Sukolilo ITS Surabaya, JI. Arief Rahman Hakim, Surabaya, Indonesia \\ ${ }^{3}$ Industrial Engineering, Faculty of Industrial Technology, The Institute of Technology (ITS), Campus Sukolilo ITS Surabaya, JI. Arief Rahman Hakim, Surabaya, Indonesia
}

\begin{abstract}
Zeolites are used as raw material to make nanofiltration membrane because they are easily obtained and cheap. The used of zeolite membranes can be an alternative wastewater treatment. One of the potential alternatives for wastewater treatment is nanofiltration membranes with pore size of $0.001 \mu \mathrm{m}$ filtered high organic content of laundry which contained high turbidity and phospate. The content of turbidity and phosphate in the laundry wastewater is needed to treat before being discharged into river. The purpose of this study is to determine the value of rejection and flux for each variation of concentration. Variation of concentration that used were pure wastewater which dilluted with tap water in ratio $100 \%, 75 \%$, and $50 \%$. Based on this research, the characteristics of laundry waste water before filtration process are turbidity parameters showed for $100 \%, 75 \%$ and $50 \%$ are 151 NTU, 146 NTU, 143 NTU and for phosphate parameters are $31.30 \mathrm{mg} / \mathrm{L}, 25.8 \mathrm{mg} / \mathrm{L}$ and $11.49 \mathrm{mg} / \mathrm{L}$. After filtration process, the highest rejection value of turbidity for each dilluted concentrations $100 \%, 75 \%, 50 \%$ are $88.46 \%, 87.82 \%, 87.58 \%$. The highest flux value for each dilluted concentrations $100 \%, 75 \%$ and $50 \%$ are $7,22 \mathrm{~L} / \mathrm{m}^{2}$.hour, $8,49 \mathrm{~L} / \mathrm{m}^{2}$.hour and $11,04 \mathrm{~L} / \mathrm{m}^{2}$.hour.
\end{abstract}

Keywords: Cross flow; Laundry wastewater; Nanofiltration; Zeolite

\section{Introduction}

Nanofiltration membranes have a pore size of $0.001 \mu$ which can filter waste water from low organic content until high organic content [1]. Nanofiltration is also used for water softening, removal of micro pollutants such as sewage treatment and wastewater. So it can be used for laundry wastewater treatment alternatives [2].

Natural zeolite is a suitable material in the fabrication of membrane because it is not easy to inflate in water and easily form a suspension to coat the membrane as a support [3]. Membrane based zeolite are also used widely for the separation of hydrocarbon gases, solvent dehydration, as a catalyst for chemical conversion, pollutants remediation and clean water production [4]. Zeolites are used widely because of its pore structure [5]. Zeolite is a mineral natural ingredients that are available in Indonesia is quite high plentiful. In this study, the performance test of zeolite nanofiltration membranes for laundry wastewater treatment will be showed. Membrane performance is measured based on the flux and rejection values. In general, the study aims to find the ability of zeolite nanofiltration to treat laundry wastewater with using turbidity and phosphate as a parameter.

\section{Methods}

\section{Synthesis of zeolite}

Synthesis of zeolite using alkali fussion method. The process of making the membrane consists of two phases, namely the purification stage and the stage of making zeolite membranes and printing. At first zeolite with a particle size of 200 mesh was purified by the method alkali fusion immersed in 15\% hydrochloric acid solution for 24 hours to remove impurities. Deposition results $\mathrm{HCl}$ immersion rinsed with distilled water 12 to 18 times and put in the oven into a powder. $\mathrm{KOH}$ powder form mixed with a ratio of $12 \%: 88 \%$ and then entered into the furnace at a temperature of $550^{\circ} \mathrm{C}$ for 4 hours to remove organic substances. After 4 hours, the ash soaked with distilled water for 24 hours to precipitate $\mathrm{KCl}$ crystals formed. The precipitate is removed; the solution is taken, filtered, and dried. Results zeolite that has been purified white powdery substance.

\section{Preparation of membrane}

Preparation of membrane is divided into two steps. The first step is to weigh as much as 3 grams and 6 grams of powdered zeolite. Zeolite powder put in a centrifuge bottle and then added $35 \mathrm{ml}$ of 2-propanol. The mixture was then centrifuged for 10 minutes at a speed of $600 \mathrm{rpm}$. After that, the supernatant liquid on a white precipitate was removed and put in a glass beaker containing a mixture of $3.5 \mathrm{~g} \mathrm{NH}_{4} \mathrm{Cl}$ and 200 $\mathrm{ml}$ of distilled water. The mixture is then stirred using a magnetic stirrer for 1 hour.

The next stage is the mixing of sediment mixing zeolite with $\mathrm{NH}_{4} \mathrm{Cl}$ solution, distilled water, PVA (poly vinyl alcohol) and PEG (polyethylene glycol). The solution is heated until all ingredients are mixed with smooth and thickened. After the solution has thickened then printed using a small petri dish and left for 30 hours to dry. Dry membranes are browned and available for use.

\section{Membrane test in crossflow reactor}

In this research, we used three variations concentration of

*Corresponding author: Alia Damayanti, Environmental Engineering Department Faculty of Civil Engineering and Planning, The Institute of Technology (ITS), Campus Sukolilo ITS Surabaya, Jl. Arief Rahman Hakim, Surabaya, Indonesia, E-mail: lia@its.ac.id

Received February 21, 2016; Accepted March 29, 2016; Published April 04, 2016

Citation: Damayanti A, Sari TK, Afifah AS, Sutikno, Sunarno LT, et al. (2016) The Performance Operation of Zeolite as Membrane with using Laundry Waste Water. J Membra Sci Technol 6: 148. doi:10.4172/2155-9589.1000148

Copyright: (C) 2016 Damayanti A, et al. This is an open-access article distributed under the terms of the Creative Commons Attribution License, which permits unrestricted use, distribution, and reproduction in any medium, provided the original author and source are credited. 
wastewater. Variation of $100 \%$ consists of $100 \%$ wastewater, a variation of $75 \%$ consists of $75 \%$ wastewater and $25 \%$ tap water, and variations of $50 \%$ consist of $50 \%$ wastewater and $50 \%$ tap water. Membrane with diameter $3 \mathrm{~cm}$ placed in cross flow reactor with using 5 bar pressure. Laundry wastewater will be pumped to the membrane reactor using a booster pump. Flux and permeate will be analyzed every 20 minutes to know the differences turbidity and phosphate before and after filtration. Cross flow reactor used can be seen in Figure 1.

\section{Analysis of samples}

Analysis of samples was using influent and effluent point. Permeate sampling point is shown in Figure 1. The method for turbidity analysis is based on the ISO 06-6989.25-2005, while the analysis of phosphate in laundry wastewater based on the ISO 06-6989.31-2005.

\section{Analysis of membrane morphology}

Morphological analysis was conducted using SEM EDX (Scanning Electron Microscopy with Energy Dispersive X-ray Spectroscopy). Analysis SEM EDX was examined the morphological membrane and membrane composition. Zeolite nanofiltration membrane will be analysis before and after filtration.

\section{Results and Discussion}

\section{Preliminary analysis of laundry wastewater}

Wastewater used in this study was taken in laundry wastewater Keputih area, Surabaya. Preservation of samples stored in the refrigerator at $4^{\circ} \mathrm{C}$. Before the cross flow reactor was tested on a preliminary analysis of parameters such as turbidity and phosphates. Based on the analysis results obtained initial turbidity values laundry waste water at various concentrations of $100 \%, 75 \%$, and $50 \%$ was 151 NTU, 146 NTU and 143 NTU. Initial phosphorus content of laundry wastewater at various concentrations of $100 \%, 75 \%$ and $50 \%$ was 31.30 $\mathrm{mg} / \mathrm{L}, 25.84 \mathrm{mg} / \mathrm{L}$ and $11.49 \mathrm{mg} / \mathrm{L}$.

\section{Effect the wastewater concentration to the flux value in laundry wastewater}

Flux value is the sum of the volume permeate flux passing through a unit area of membrane surface at a specified time in the presence of a thrust pressure membrane flux value is a function of pore size, porosity, thickness and structure of the membrane. Flux values affect the efficiency of the membrane separation process that depends on the structure of the membrane such as pore size distribution, pore shape, and porosity.

$$
\mathrm{J}=\frac{\mathrm{v}}{\mathrm{A} \times \mathrm{t}}
$$

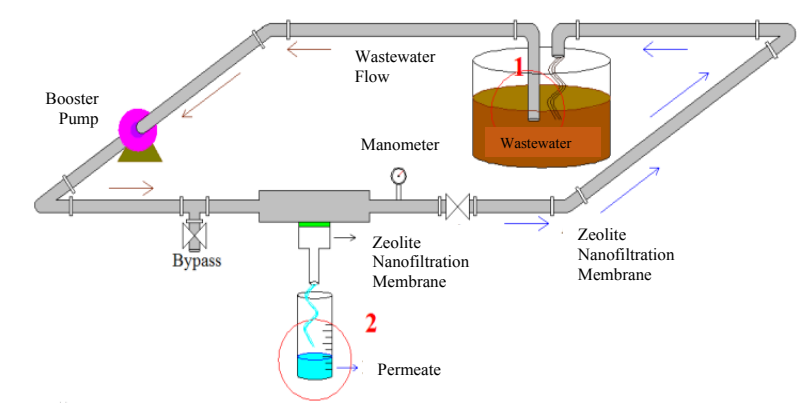

Figure 1: Crossflow reactor.

\section{$\mathrm{J}=\operatorname{Flux}\left(\mathrm{L} / \mathrm{m}^{2}\right.$.hour $)$ \\ $\mathrm{V}=$ Volume of permeate $(\mathrm{L})$ \\ $A=$ Membrane surface area $\left(\mathrm{m}^{2}\right)$ \\ $\mathrm{t}=$ Time (hour)}

Based on the results, the influence of variations in the concentration of laundry wastewater to the flux values are shown in Figure 2. The highest flux value in laundry waste generally occurs at minute 20 on the variation of wastewater concentration of $100 \%, 75 \%$ and $50 \%$. Among the variations in the concentration of wastewater, effluent concentration of $50 \%$ was the highest flux. A decline in the value of the flux is due to the length of time the operation of the membrane. The smallest value of the flux is at minute 80 filtration process. The highest flux value is obtained at a concentration of $50 \%$ of wastewater is equal to $11.04 \mathrm{~L} /$ $\mathrm{m}^{2}$.hour and continued to decline to $1.8 \mathrm{~L} / \mathrm{m}^{2}$.hour min to $80 \mathrm{~L} / \mathrm{m}^{2}$.hour. Based on research [6], the flux value will decreases with increasing time. This impairment could be due to the occurrence of flux on membrane fouling. Fouling is a phenomenon of accumulation of material on the membrane, causing the membrane pores smaller. Fouling is a phenomenon of accumulation of material on the membrane, causing the membrane pores smaller. Based on the chart above zeolite obtained the greater the mass, the lower the value of the flux. This may be due to the more mass zeolite membranes are used for the manufacture of the smaller pores formed. According to Wenten [7], the occurrence of interactions due to membrane fouling at a very specific physical and chemical between the dissolved solids with membranes. Transfer characteristics in porous membranes can be made by assuming that the membrane is composed of a parallel and uniform pores. The process of moving a molecule or particle in the membrane due to the work force on the molecule or particle. Zeolite membrane test which used at 5 bar pressure has a range of average flux values from $1.80 \mathrm{~L} / \mathrm{m}^{2}$.hour to 11.04 $\mathrm{L} / \mathrm{m}^{2}$.hour. Nanoparticles membranes can operate at a pressure of 5-20 bar and have a range of flux values from 1.4 to $12 \mathrm{~L} / \mathrm{m}^{2}$.hour [8].

Nanoparticles membrane has been largely used in some cases because increasing in membrane hydrophilicity. The same study shown by Mohammad et al. [9]. According Amoudi and Lovitt [10], nanofiltration membranes flux decline due to fouling pores because the colloidal particles contained in wastewater. Colloids are defined as particles that have a size of a few nanometers to micrometers. Clogging particles called foulan. Foulan can be classified into three types: organic (proteins and carbohydrates), inorganic (clays and metal oxides) and biological (bacteria and other microorganisms). Membrane pores are getting smaller due to foulan on the surface of this membrane causes the feed water passes through the membrane the less so that the smaller

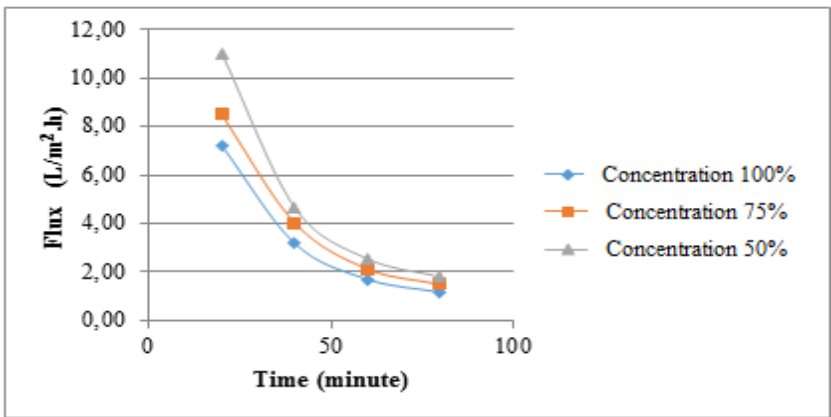

Figure 2: Graphic of flux value membrane in the variation concentration. 
flux. Beside the flux declined cause of fouling phenomena, it is also can be because of biofouling phenomena [11]. A Biofouling phenomenon is one type instances of fouling that active organism such as active microorganisms, fungi, viruses, and extra polymeric substances play rolled as a subject. Biofouling phenomena can be reduced and mitigated by using $\mathrm{TiO}_{2}$ as membrane coating, $\mathrm{UV}$, and or coorporation between copper, selenium, and zinc in the materials manufacture of membranes [12].

\section{Effect the concentration of wastewater rejection value for turbidity parameter in laundry wastewater}

Rejection value describes the permselectivity rejection of membrane. Permselectivity is a measure of the membrane ability to withstand a species or skip a particular species. The higher rejection value indicates rejection membranes have a high degree of selectivity. Rejection value calculation using the formula:

$$
\mathrm{R}=1-\frac{\mathrm{Cp}}{\mathrm{Cf}} \times 100 \%
$$

Where:

\section{$\mathrm{R}=$ Rejection value (\%)}

$\mathrm{C}_{\mathrm{p}}=$ Permeate concentration $(\mathrm{mg} / \mathrm{L})$

$\mathrm{C}_{\mathrm{f}}=$ Feed concentration $(\mathrm{mg} / \mathrm{L})$

$R$ values range from 0 to 1 . If the value of $R=1$ means the contaminants completely retained by the membrane. Determination of membrane rejection rate associated with the membrane porosity. Porosity is the ratio area of the membrane pore size. The smaller the size of the membrane, the higher is resulting porosity and vice versa. If rejection value membranes showed $100 \%$ means that the membrane having a perfect rejection, if the rejection value is $0 \%$ which indicate that the solution and solutes pass through the membrane freely. Graphs of the parameter values of membrane rejection turbidity in wastewater concentration variations can be seen in Figure 3 .

Based on Figure 3, at a wastewater concentration of $100 \%$ wastewater rejection turbidity values occurred at minute 80 was $88.46 \%$. At a concentration of $75 \%$ wastewater, rejection values show an increase with increasing operating time. Value of successive rejection of minutes to 20 to 80 minutes for $83.71 \%$; $83.96 \%$; $86.61 \%$; $87.82 \%$. At a concentration of $50 \%$ waste water, rejection turbidity values in a row from minute 20 to minute 80 by $78.57 \% ; 82.52 \% ; 85.33 \% ; 87.58 \%$. Concentration of wastewater $100 \%$ generally have a higher rejection rate than the concentration waste water $75 \%$ and $50 \%$. Turbidity values can be affected by suspended solids or solids contained in the waste water as well as organic and inorganic materials in the form of plankton and other microorganisms [13]. The greater the concentration of waste water showed turbidity levels resulting in a growing number of increasingly rapid fouling. The formation of fouling indirectly provide for the filtering effect of feed water passes through the membrane so that with increasing time the resulting permeate quality will be better characterized by an increased rejection rate.

According to [8], a membrane-based separation processes separation process by retaining one of the components and skip the other components. the process with a pressure thrust, when the thrust force working on the feed side then some parts of dissolved solids are retained on the membrane will pass while the solvent to penetrate the membrane. This causes the permeate concentration becomes lower than the feed concentration of the basic concept of separation with membranes. Accumulation of solid particles called concentration polarization/fouling will be retained on the surface of the membrane thus increasing the concentration of solids on the membrane surface. The concentration polarization will greatly affect the selectivity.

In the span of 80 minutes of operation during rejection rate remains constant. This indicates that the rate of fouling is still not too high so that the membrane is still able to filter wastewater.

\section{Effect the concentration of wastewater rejection value for phospate parameter in laundry wastewater}

Tests to determine the value of a zeolite membrane rejection phosphate performed for 80 minutes with taking permeate every 20 minutes. Graphic rejection phosphate values are shown in Figure 4.

Based on the graph, the decrease in phosphate content conducted because of the rejection ability of membrane molecules larger than the pore diameter membrane and molecules with a diameter smaller than the membrane pores can pass through the membrane. Orthophosphate is multivalent ions are trivalent 3 and 2. According to Ren and Wang [14], nanofiltration membranes can separate divalent ions so that in this case, the phosphate content contained in the laundry wastewater by nanofiltration membranes can reject because phosphate ions retained on the membrane. The process follows the movement of molecules through the membrane diffusion mechanisms are influenced by the size or molecular weight of the solute. The larger the size of the solute molecules will be more difficult for the solute diffuses across the membrane. Therefore, the concentration of solid in permeate becomes smaller.

Based on this study, the relationship between the value of the membrane flux and rejection values are opposite to each other. Higher flux values indicate increasing number of solvent water in permeate. Increasing the amount of solvent in the permeate water is much greater than the increase in the amount of solute in permeate. This will result in

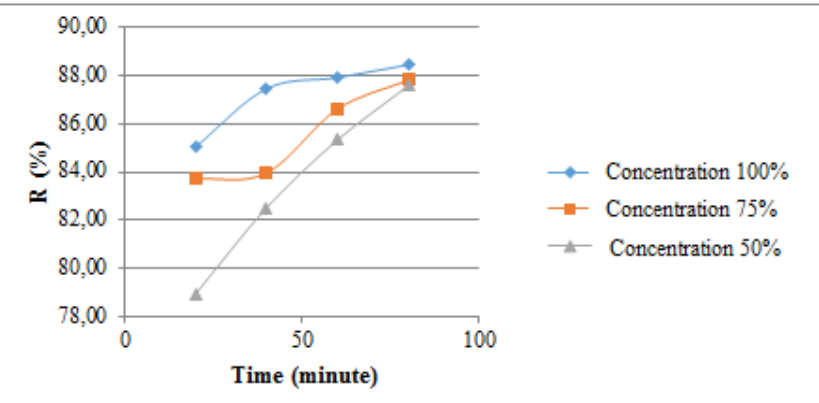

Figure 3: Graphic of turbidity rejection value in laundry wastewater.

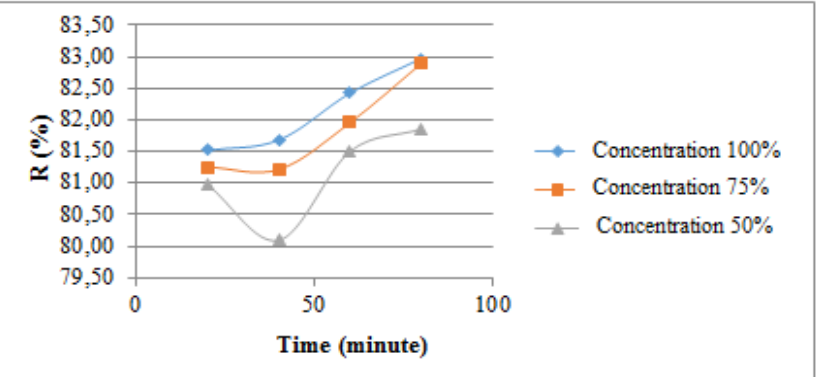

Figure 4: Graphic of phospate rejection value phospate in laundry wastewater 
Citation: Damayanti A, Sari TK, Afifah AS, Sutikno, Sunarno LT, et al. (2016) The Performance Operation of Zeolite as Membrane with using Laundry Waste Water. J Membra Sci Technol 6: 148. doi:10.4172/2155-9589.1000148

Page 4 of 4

the concentration of solute in permeate becomes increasingly decreased with increasing the amount of water in permeate. It can also be said that the higher the value, the more flux of solutes across the membrane. This will result in the concentration of solutes in the permeate will also increase or decrease the rejection rate [10].

\section{Analysis of Membrane Morphology}

Analysis of the morphology of the membrane using a scanning electron microscopy with energy dispersive X-ray spectroscopy (SEM EDX): SEM analysis performed before and after membrane filtration is used to process wastewater. Membranes were used for SEM analysis performed on membranes that have the highest rejection rate analysis results of SEM Photos waste laundry membranes is shown in Figure 5.

In Figures 5 and 6 shows the SEM photos of the membrane before and after the filtration process used to look different. Membrane looks increasingly congested due to the occurrence of fouling. Fouling leads to blockage of the pores in the membrane due to a buildup of material on the membrane surface. Fouling on the membrane surface does not only occur in the upper or outer layer of the membrane that forms the only cake but also the outer layer of the membrane is possible. Impurities that enter into the inner layer are the result of pressure exerted during the membrane operation. The pressure will encourage the deposition of particles on the membrane surface [15].
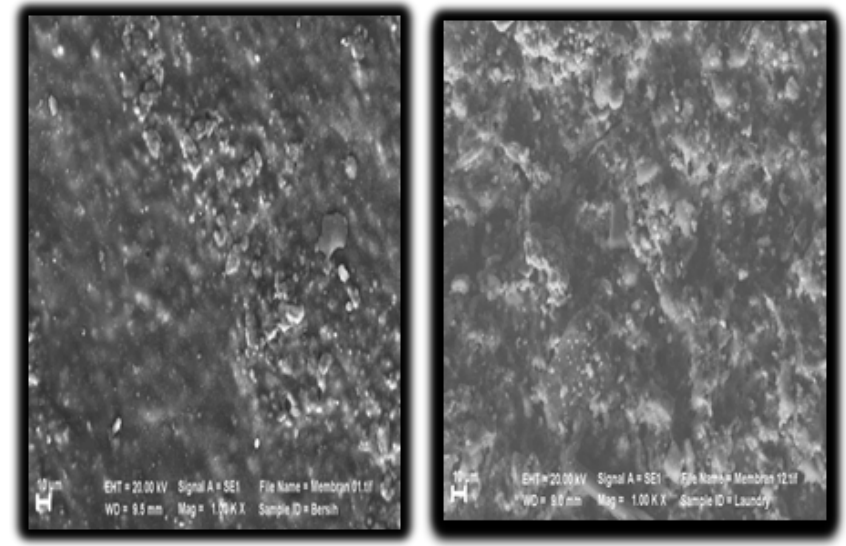

Figure 5: SEM images of membrane before (left) and after (right) filtration.
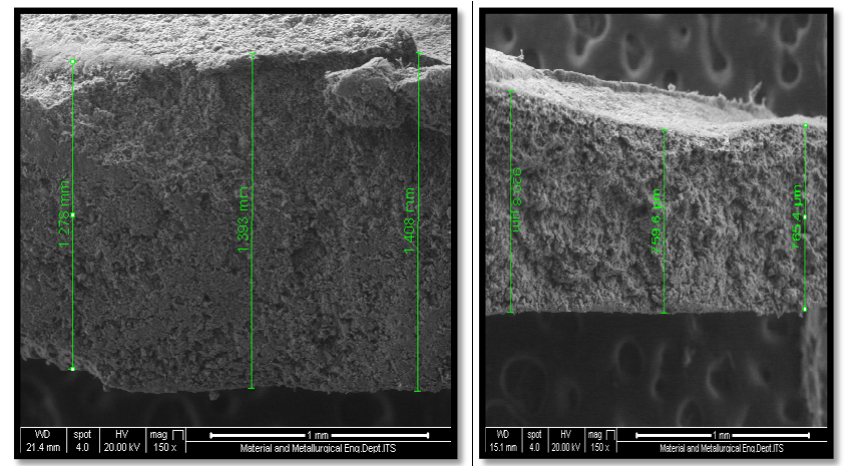

Figure 6: SEM images of membrane before (left) and after (right) filtration.

\section{Conclusion}

Based on the study obtained several conclusions that the highest flux value at 100\%:75\%:50\% concentration of laundry wastewater are $7.22 \mathrm{~L} / \mathrm{m}^{2}$.hour, $8.49 \mathrm{~L} / \mathrm{m}^{2}$.hour and $5.02 \mathrm{~L} / \mathrm{m}^{2}$.hour. The highest rejection value at 100\%:75\%:50\% concentration of laundry wastewater for turbidity parameters are $88.46 \% ; 87.82 \% ; 87.58 \%$. The highest rejection value at 100\%:75\%:50\% concentrations of laundry wastewater for phospate parameters are $82.97 \% ; 82.90 \% ; 81.85 \%$. The used of zeolite membrane as nanoparticles membrane has been largely used in some cases because increasing in membrane hydrophilicity.

\section{Acknowledgements}

Thank you to Ministry of Higher Education Indonesia for funding this study through Vot Number 003246.10/IT2.11/PN.08/2015.

\section{References}

1. Damayanti A, Ujang Z, Salim MR (2011) The influenced of PAC, zeolite and moringa oleifera as biofouling reducer (BFR) on hybrid membrane bioreactor of palm oil mill effluent (POME). Bioresour Technol 102: 4341-4346.

2. Gomes S, Cavaco SA, Margarida J, Licinio MQ, Gando-Ferreira (2010) Nanofiltration process for separating $\mathrm{Cr}$ (III) from acid solution: experimenta and modelling analysis. Desalination 254: 80-89.

3. Dong Y, Chena S, Zhang X, Yang J, Liu X (2006) Fabrication and characterization of low cost tubular mineral-based ceramic membranes for micro-filtration from natural zeolite. J Memb Sci 281: 592-599.

4. Cui J, Zhang Z, Liu H, Liu S, Yeung KL (2008) Preparation and application of zeolite/ceramic microfiltration membranes for treatment of oil contaminated water. J Memb Sci 325: 420-426.

5. Shan W, Zhang Y, Yang W, Ke C, Gao Z, et al. (2004) Electrophoretic deposition of nanosized zeolites in non-aqueous medium and its application in fabricating thin zeolite membranes. Microporous and Mesoporous Material 69: 35-42.

6. dan Damayanti AA (2013) Pengolahan limbah laundry menggunakan membran nan ofiltrasi aliran cross flow untuk menurunkan kekeruhan dan fosfat. Jurnal Teknik Pomits 2: 2

7. Wenten IG (1996) Membrane technologi for industry and environmental protection, UNESCO. Center for membrane science and technology ITB.

8. Mulder M (1996) Basic Principles of membrane technology ( $2^{\text {nd }}$ edn.) Kluwer Academic Publishers, London.

9. Mohammad AW, Teow YH, Ang WL, Chung YT, Oatley-Radcliffe, et al. (2015) Nanofiltration membrane review: recent advances and future prospects. Desalination 356: 226-254

10. Al-Amoudi A, Lovitt RW (2007) Fouling strategies and the cleaning system of NF membrane and factors affective cleaning efficiency. J Memb Sci 303: 4-28

11. Damayanti A, Ujang Z, Salim MR, Ollsong G (2011) The effect of mixed liquor suspended solids (MLSS) on biofouling in a hybrid membrane bioreactor for the treatment of high concentration of organic water. Water Science and Technology 63: 1701-1706

12. Kohkodan V, Hilal N (2015) A comprehensive review on surface modified polymer membrane for biofouling mitigation. Desalination 356: 187-207.

13. Effendi H (2003) Telaah Kualitas Air. Kanisius, Yogyakarta.

14. Ren J, Wang R (2011) Preparation of Polymeric Membranes. Handbook of Environmental Engineering 13: 47-100

15. Puspayana DR, Damayanti A(2013) Pengolahan limbah cair tahu menggunakan membran nanofiltrasi silika aliran cross flow untuk menurunkan kadar nitrat dan amonium. Journal Teknik Pomits 2: 2 . 